\title{
The addition of the thermophilic esterase EST2 influences the fatty acids and volatile compound profiles of semi hard cheeses
}

\author{
Valentina DE LUCA ${ }^{1}$, Maria Cristina PEROTTI², Irma Veronica WOLF², Carlos Alberto MEINARDI ${ }^{2}$, \\ Luigi MANDRICH ${ }^{1 *}$
}

\begin{abstract}
During cheese ripening the hydrolytic activities of proteases and lipases are essential to develop typical flavours; usually these activities come from lactic bacteria. A way to increase cheese flavour and/or to reduce the time of ripening is the addition of exogenous enzymes during cheese making. Actually some commercial lipases are used in cheese making, here we have evaluated the effect of the addition of the thermophilic esterase EST2, from Alyciclobacillus acidocaldarius, on the lipolysis and volatile compounds profiles of semi-hard cheeses. The addition of EST2 produced an increase of the degree of lipolysis up to $30 \%$ and the relative proportion of short- and medium- chain fatty acids, with respect to the control cheese. By SPME-GC-FID/MS were identified 27 and 31 volatile compounds in control and EST2-added cheeses, respectively; showing higher values than control for almost all compounds studied. EST2 addition during cheese making intensified the production of flavour compounds, suggesting a preferential release of short chain fatty acids. Considering that esterases have a different mechanism of action respect to lipases and EST2 is much more stable respect to all the commercial lipases, it could be an interesting technological tool to improve the sensory quality or to accelerate cheese ripening.
\end{abstract}

Keywords: exogenous esterase; cheese making; cheese flavour; lipolysis; EST2 from Alicyclobacillus acidocaldarius.

Practical Application: Increase cheese flavour and reduce time of cheese ripening.

\section{Introduction}

The flavour of mature cheese is the result of a complex series of biochemical events, especially catalysed from hydrolytic enzymes, which occur in the curd during ripening. Proteolytic digestion of cheese matrix is considered to be a multi-step reaction involving the formation of rather large well-defined peptides, and their subsequent degradation into smaller peptides and finally in amino acids (Fox, 1993; Marilley \& Casey, 2004; Smit et al., 2005). Lipolysis is produced by lipolytic enzymes, which are hydrolases that cleave the ester linkage between a fatty acid and the glycerol core of the triacylglyceride, producing free fatty acids (FFA), and mono- and diacylglycerides (Collins et al., 2003). Free fatty acids and amino acids act mainly as precursors of a series of catabolic reactions, not well understood, leading to the production of aroma compounds, such as fatty acids, esters, aldehydes, alcohols, ketones, hydrocarbons, lactones and sulphur compounds, among other, giving to each cheese its typical sensory characteristics (Yvon \& Rijnen, 2001; Collins et al., 2003). Lipolysis does not occur to a large extent in most of cheese types, although it is very important in the flavour generation in blue and surface-ripened (smear) cheeses, and in hard cheeses such as certain Italian varieties (Parmigiano Reggiano, Provolone, Pecorino Romano) in which lipases-and esterases- rich rennet paste, are used in the manufacture (Battistotti \& Corradini, 1993; Collins et al., 2003). In some cases, the incorporation of exogenous lipases during the cheese-making process, has been used to replace the rennet paste, in order to standardize the production and control of the flavour in the final product, otherwise highly variable depending on the enzymatic composition of these coagulants (Hernández et al., 2005). The use of exogenous lipases in the dairy industry has been reported for over 40 years (Harboe, 1994), to enhance the cheese flavour and to accelerate cheese ripening, a slow and relatively expensive process in the dairy industry (El Soda, 2003; Upadhyay et al., 2004). Nevertheless, enzyme addition suffers of some limitations related to the selection of the most adequate enzyme, the correct method and the right amount of enzyme to be added in each case, and for the presence of secondary enzymatic activities in some commercial preparations. From the economic viewpoint, this strategy has the disadvantage that only a small portion of the enzyme added to the milk is retained in the curd. Micro-encapsulation of the enzyme before addition to milk helps its retention in the curd, reducing the loss of the enzyme in the whey (El Soda, 2003; Upadhyay et al., 2004; El-Hofi et al., 2011). Several preparations of lipases commercially available derived from moulds (Aspergillus sp., Rhizomucor miehei, Pseudomonas fluorescens), from calf and porcine pancreas have been used in some cheese varieties such as Provolone, Romano, Feta, etc. (Harboe, 1994; Kilara, 2003; Upadhyay et al., 2004), and lipase form potato (Spelbrink et al., 2015).

Received 01 Mar., 2018

Accepted 02 Oct., 2018

${ }^{1}$ Institute of Protein Biochemistry, National Research Council, Naples, Italy

${ }^{2}$ Instituto de Lactologia Industrial - INLAIN, Universidad Nacional del Litoral - UNL, Consejo Nacional de Investigaciones Científicas y Técnicas - CONICET, Santa Fe, Argentina

${ }^{*}$ Corresponding author: 1.mandrich@ibp.cnr.it 
The aim of this work was to evaluate the effect of the addition of an exogenous esterase on the lipolysis and volatile compounds profiles of semi-hard cheeses. The esterase EST2 is a thermophilic esterase isolated from Alicyclobacillus acidocaldarius, cloned, purified and characterized from a biochemical and structural point of view (Manco et al., 1998, 2001; De Simone et al., 2000). This enzyme have an optimal temperature of $70^{\circ} \mathrm{C}$, remarkable temperature stability with a half-life of $3 \mathrm{~h}$ at $75^{\circ} \mathrm{C}$, and exhibits maximal activity at $\mathrm{pH} 7.0$ with $p$-Nitrophenyl-esters with acyl chains that are six to eight carbon atoms long (Manco et al., 1998). It's important to note that between lipases and esterases there is same fundamental differences, lipases act on micellar esters and structurally they have the catalytic site closed by a lid domain which is activated and open by the contact with micellar substrate (Khan et al., 2017); instead esterases act on soluble esters and structurally lack of the lid, moreover preferentially they hydrolyze substrates with a short acyl chain (4-10 carbon atoms) (Arpigny \& Jaeger, 1999).

In a previously work the ability of EST2 to synthesize esters and thioesters in milk and cheese models was studied (Mandrich et al., 2006). The satisfactory results obtained suggested its potential use in the dairy industry to develop characteristic flavour and/or to accelerate cheese ripening (Mandrich et al., 2006).

\section{Materials and methods}

\subsection{Mini-curds making}

To study the degree of integration of EST2 in cheese matrix, mini-curds with approx. $50 \mathrm{~mL}$ of milk were made [Institute of Protein Biochemistry, CNR, Italy]. Milk acidification was obtained by addition of $0.5 \mathrm{M}$ citric acid pH 1.5 (Sigma-Aldrich, USA), and than of $1 \mathrm{~mL}$ of diluted rennet powder was added $(1 \mathrm{mg} / \mathrm{mL}$, in $20 \mathrm{mM}$ sodium phosphate buffer $\mathrm{pH}$ 5.5, $860 \mathrm{IMCU} / \mathrm{g}$; rennet powder was kindly gift from Caglificio Clerici S.p.a., Italy). In these trials were used both whole milk (about $3 \%$ of fat) and low fat milk ( $<0.02 \%$ of fat). Western blot analysis was exploited as method for enzyme semi-quantitation in milk, mini-curds and whey. A concentration of $20 \mathrm{ng} / \mathrm{mL}$ of EST2 was added to milk. Western blot analysis was performed to detect EST2 in cheese matrix. Briefly, $2 \mathrm{~g}$ of cheese were dissolved in $13 \mathrm{~mL}$ of $0.5 \mathrm{M}$ sodium citrate buffer $\mathrm{pH} 5.5$ and boiled $15 \mathrm{~min}$; the soluble fraction was used for western blot analysis (Manco et al., 1998). EST2 retained in the samples was quantified by densitometric analysis of western blot filters using ChemiDoc equipment (Bio Rad, USA). As standard of western blot analysis were used increasing quantities of EST2 from 5 to $100 \mathrm{ng}$. The residual esterase activity of EST2 was measured on the whey by standard spectrophotometric assay (Manco et al., 1998). Results are mean of two independent experiments.

\subsection{Cheese making trials}

The standard process for production of a semi-hard cheese was adapted to laboratory scale and applied to obtain semi-hard cheeses. Five vats of $5.5 \mathrm{~L}$ of capacity were operated simultaneously [Instituto de Lactologìa Industrial (INLAN), Santa Fe, Argentina]; one cheese of about $600 \mathrm{~g}$ was obtained from each vat (Meinardi et al., 2002).
Two trials of cheese making were performed using four different concentrations of EST2: 2, 5, 10 and $20 \mathrm{mg} / \mathrm{L}$ of milk (indicated as experimental cheeses, $\mathrm{E}_{\mathrm{I}}-\mathrm{E}_{\mathrm{IV}}$ ) and without enzyme (control cheeses, C). Raw bulk cow milk (fat $3.6 \pm 0.1 \% \mathrm{w} / \mathrm{v}$, protein $3.2 \pm 0.05 \% \mathrm{w} / \mathrm{v}$ ) was supplied by a nearby dairy plants on each cheese making day.

The milk was standardized to $3.4 \%$ of fat and pasteurized at $65^{\circ} \mathrm{C}$ for 20 minutes. After cooling to $35^{\circ} \mathrm{C}$, was added EST2 enzyme, $\mathrm{CaCl}_{2}$ and the starter at concentration of $10^{6} \mathrm{UFC} / \mathrm{mL}$ of milk in all vats (Reinheimer et al., 1996). After 15 minutes of manual stirring, $1 \mathrm{~g}$ of chymosin was added in all vats (MAXIREN-150, Gist Brocades, France; 100\% chymosin, rennet strength 150,000 IMCU/mL). When the curd reached the appropriate strength, it was cut to the adequate grain size $(8-10 \mathrm{~mm})$ and the mixture of the curd particles and whey was heated until $45^{\circ} \mathrm{C}$ at the rate of $1{ }^{\circ} \mathrm{C} / \mathrm{min}$, under stirring. Then the curd was put in moulds, pressed to facilitate whey expulsion during $20 \mathrm{~h}$ and brined for $7 \mathrm{~h}$ in saturated brine $(20 \%)$ at $12{ }^{\circ} \mathrm{C}$. Cheeses were ripened at $12 \pm 1{ }^{\circ} \mathrm{C}$ and $85 \pm 4 \%$ of relative humidity for 60 days. At two weeks of ripening they were wrapped in plastic film to avoid over drying.

\subsection{Cheese sampling}

Cheese samples were taken for analyses at the end of ripening according to the standard methods of International Dairy Federation (International Dairy Federation, 1995: 50C). Each sample was obtained by cutting two cylindrical portions of approximately $10 \mathrm{~g}$ each, from the center of the cheese to the lateral surface. The outer $10 \mathrm{~mm}$ of the cheese cylinders were discarded. Due to the gradient of moisture and salt concentration along the radius of the cheese, each cylinder was grated and the samples were kept at $-18{ }^{\circ} \mathrm{C}$ until analysis.

\subsection{Global composition of cheese and degree of ripening}

Cheeses were analyzed in duplicate for moisture (oven drying at $102 \pm 1{ }^{\circ} \mathrm{C}$, International Dairy Federation, 1982: 4A), protein content (macro-Kjeldahl; International Dairy Federation, 1993: 20B), and fat content (Gerber-Van Gulik method, International Organization for Standardization, 1975). The $\mathrm{pH}$ was measured in according to the method of the American Public Health Association (APHA) (Bradley et al., 1993).

To calculate the degree of ripening, the soluble nitrogen (SN) at pH 4.6 was determined according to Gripon et al. (1975). The nitrogen content was determined by the macro-Kjeldhal method and the values were expressed as percentage of total nitrogen.

\subsection{Free fatty acids analysis by GC-FID}

Extraction of cheese lipids, isolation of free fatty acids (FFA), derivatization to ethyl esters, and determination of their concentrations by gas-liquid chromatography were carried out in duplicate as described by Perotti et al. (2005). Other details are reported in Appendix A ( $i)$. The results were expressed as mg of FFA per $\mathrm{kg}$ of cheese. 


\subsection{Volatiles compounds profiles by GC-FID-MS}

A manual SPME device equipped with a $1 \mathrm{~cm} \times 50 / 30 \mu \mathrm{m}$ Stable-Flex DVB/CAR/PDMS (Supelco, USA) was used to isolate and concentrate the volatile compounds. Five grams of grated cheese was weighed in a $30 \mathrm{~mL}$ glass vial and hermetically sealed with aluminum seal and butylteflon septa. Other details are reported in Appendix A (ii). Both, mass spectrometric identifications and chromatographic peaks of FID, were further confirmed by comparing retention times with reference standards (Sigma-Aldrich, USA) or bibliographical data (Mallia et al., 2005; Ziino et al., 2005; Povolo et al., 2007; Wolf et al., 2011). The results were expressed as peak areas in arbitrary units. The analysis was conducted in duplicate.

\subsection{Sensory evaluation}

Sensory analysis of cheeses was performed by a triangle test to determine whether a sensory difference existed among experimental and control cheeses at the end of ripening. This method is used when the effects of treatment may have produced changes in the product that cannot be characterized simply by one or two attributes.

Cheeses samples were refrigerated for up to $24 \mathrm{~h}$ prior to analysis. Three coded samples were presented at random to a non-trained panel of 24 members. The subjects were asked to examine the samples in order from left to right and select the different samples. The correct answers were counted and the results were interpreted using tables at 95\% confidence level.

\subsection{Statistical analysis}

The SPSS package v. 10.0 (SPSS Inc., Chicago, IL, USA) was used for statistical analysis of the results. One-way analysis of variance (ANOVA) was performed to establish the presence or absence of significant differences in the gross composition, concentrations of FFA and volatile compounds areas evaluated in cheeses. The differences among means were detected by Least Significant Difference (LSD) Multiple Range Test.

\section{Results and discussion}

Recently it has been published a paper by Spelbrink et al. (2015), where was purified a lipase from potato (patatin lipase), used in cheese making and tested for its activity on the flavour formation, this enzyme shown the maximum activity on tri-acyl glycerols with acyl chain length from 6 to 8 carbon atoms; before this paper Hernández et al. (2005) have used three different commercial lipases, two from animals and the third from Aspergillus niger, to test their effect on lipolysis during cheese ripening. The authors have measured some parameters about the effect on cheese ripening and flavour of the commercial and patatin lipases that we have compared with the results obtained by adding EST2.

\subsection{Behavior of exogenous esterase EST2 in milk and mini-curds}

Purified EST2 was added to the milk to make mini-curds (see Materials), the amount of cheese paste obtained was about $5 \mathrm{~g}$, starting from $50 \mathrm{~mL}$ of milk. After separation of curd from whey the level of enzyme was measured by spectrophotometric esterase assay and western blot analysis (Manco et al., 1998, 2001). By spectrophotometric assay was calculated that EST2 retained in whey shown about $90 \%$ of its initial activity, whereas the patatin lipase shown only about $40 \%$ of its initial activity (Spelbrink et al., 2015). By western blot analysis an enrichment of EST2 was observed in mini-curds made from whole milk (50 ng/g) respect to the corresponding whey where is only $15 \mathrm{ng} / \mathrm{g}$ (Table 1), and no difference were observed between whey and curd derived from low fat milk (Table 1), indicating that EST2 is associated with fats present in milk.

\subsection{Analysis of cheeses manufactured at pilot scale}

The addition of EST2 did not alter the steps of milk coagulation and separation of whey during cheese making. Analysis by western blot confirmed that the enzyme distribution between curd and whey was the same as that obtained by the lab scale preparation.

\subsection{Global composition}

In Table 2 are reported the results of the global chemical composition for control and experimental cheeses after 60 days of ripening; $\mathrm{pH}$, degree of ripening, moisture, fats and proteins content were analyzed. Protein content, $\mathrm{pH}$ values and degree of ripening were similar to those reported for semi-hard cheeses (Bergamini at al., 2006). Statistical differences were not found between experimental and control cheeses $(\mathrm{P}<0.05)$. Therefore, the incorporation of esterase in cheeses did not modify the ripening profile.

\subsection{Sensory analysis}

The results of the triangle test reveled significant differences $(\mathrm{P}<0.05)$ among $\mathrm{E}_{\mathrm{II}}, \mathrm{E}_{\mathrm{III}}, \mathrm{E}_{\mathrm{IV}}$ and $\mathrm{C}$. However, experimental cheeses with lower levels of enzyme $\left(\mathrm{E}_{\mathrm{I}}\right)$ had no significant differences $(P>0.05)$ with respect to the control cheese.

Taking into account these results, data for protein, FFA and volatile compound profiles will be presented only for experimental cheeses different from the controls.

\subsection{Lipolysis profiles}

In order to quantify and compare lipolysis among control and EST2-added cheeses, the concentration of ten FFA was calculated after 60 days of ripening and results are shown in Figure 1.

Table 1. EST2 concentration in mini-curds making. Approximately we considered $1 \mathrm{~mL}$ of milk corresponding at $1 \mathrm{~g}$ of weight; $20 \mathrm{ng} / \mathrm{g}$ is the initial concentration of EST2 added in milk; in whey and cheese paste EST2 was calculated by western blot analysis. Results are mean of two independent experiments.

\begin{tabular}{cccc}
\hline & \multicolumn{3}{c}{ EST2 concentration $(\mathrm{ng} / \mathrm{g})$} \\
\cline { 2 - 4 } & in milk & in whey & in cheese paste \\
\hline Whole milk & $\mathbf{2 0}$ & $\mathbf{1 5 . 0} \pm \mathbf{0 . 2}$ & $\mathbf{5 0 . 0} \pm \mathbf{0 . 3}$ \\
Low fat milk & $\mathbf{2 0}$ & $\mathbf{1 8 . 3} \pm \mathbf{0 . 3}$ & $\mathbf{1 7 . 3} \pm \mathbf{0 . 2}$ \\
\hline
\end{tabular}


Table 2. Global composition of control $(\mathrm{C})$ and experimental $\left(\mathrm{E}_{\mathrm{I}}\right.$ to $\left.\mathrm{E}_{\mathrm{IV}}\right)$ cheeses, calculated after 60 days of ripening. Results are mean of two independent experiments.

\begin{tabular}{|c|c|c|c|c|c|}
\hline Cheese type & Moisture content & Fats content & Proteins content & $\mathrm{pH}$ & Degree of ripening \\
\hline $\mathrm{C}$ & $39.26 \pm 0.98$ & $35.18 \pm 1.06$ & $24.76 \pm 0.42$ & $5.06 \pm 0.08$ & $8.50 \pm 0.45$ \\
\hline $\mathrm{E}_{\mathrm{I}}$ & $38.69 \pm 0.84$ & $34.45 \pm 0.87$ & $23.93 \pm 0.34$ & $5.09 \pm 0.06$ & $9.33 \pm 0.42$ \\
\hline $\mathrm{E}_{\mathrm{II}}$ & $39.05 \pm 0.79$ & $33.35 \pm 0.92$ & $24.17 \pm 0.39$ & $5.05 \pm 0.05$ & $8.97 \pm 0.32$ \\
\hline $\mathrm{E}_{\mathrm{III}}$ & $39.32 \pm 0.73$ & $33.96 \pm 0.79$ & $24.57 \pm 0.37$ & $5.06 \pm 0.09$ & $9.35 \pm 0.29$ \\
\hline $\mathrm{E}_{\mathrm{JV}}$ & $38.84 \pm 0.85$ & $34.10 \pm 0.89$ & $25.07 \pm 0.43$ & $5.08 \pm 0.04$ & $8.14 \pm 0.42$ \\
\hline
\end{tabular}

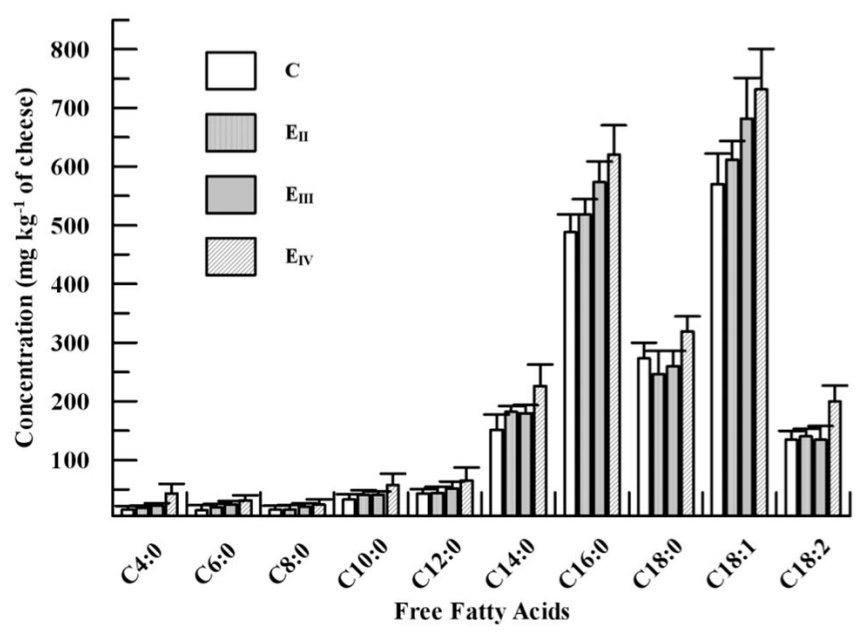

Figure 1. Lipolytic profiles of free fatty acid (FFA) analyzed by GC-FID, from the Control (C) and Experimental ( $\left.\mathrm{E}_{\mathrm{II}}, \mathrm{E}_{\mathrm{III}}, \mathrm{E}_{\mathrm{IV}}\right)$ cheeses. Results are mean of two independent results.

The extent of lipolysis (taken generally as the total concentrations of FFA), varied from $1700 \mathrm{mg} / \mathrm{kg}$ in cheeses without esterase addition (C) up to $2300 \mathrm{mg} / \mathrm{kg}$ in cheeses made with the highest amount of EST2 $\left(\mathrm{E}_{\mathrm{IV}}\right)$. These differences observed were significant, having $\mathrm{P}<0.05$, in fact the experimental cheeses shown a degree of lipolysis of about 5, 15 and 30\% higher than the control cheese, for $\mathrm{E}_{\mathrm{II}}, \mathrm{E}_{\mathrm{III}}$ and $\mathrm{E}_{\mathrm{IV}}$ respectively, indicating that there is an increasing effect on lipolysis by the presence of EST2, and the effect is dose-dependent (Figure 1). These results were in agreement with those obtained by Hernández et al. (2005) for Idiazabal cheeses supplemented with lipases, and with the results obtained in Gouda cheese added with patatin lipase (Spelbrink et al., 2015).

The lipolysis profiles shown that the group of long chain fatty acids (LCFA, $\mathrm{C}_{14: 0}-\mathrm{C}_{18: 2}$ ) was the most important group, although they are not the main contributors to cheese flavour. Palmitic $\left(\mathrm{C}_{\text {16:0 }}\right)$ and oleic $\left(\mathrm{C}_{18: 1}\right)$ acids were quantitatively the main acids found in all cheeses, and myristic $\left(\mathrm{C}_{14: 0}\right)$ and stearic $\left(\mathrm{C}_{18: 0}\right)$ acids were the following FFA, in decreasing order of concentration.

Statistically significant $(\mathrm{P}<0.05)$ differences in the contents of $\mathrm{C}_{16: 0}, \mathrm{C}_{18: 1}, \mathrm{C}_{14: 0}, \mathrm{C}_{4: 0}$ and $\mathrm{C}_{6: 0}$ were found among the experimental cheeses, whereas no significant differences were observed for the other fatty acids. Cheeses with the highest level of esterase $\left(\mathrm{E}_{\mathrm{IV}}\right)$ had the higher values. However, most notable differences were found in the relative proportion of the groups of short- and medium- chain fatty acids (SCFA, $\mathrm{C}_{4: 0}-\mathrm{C}_{8: 0}$, and MCFA, $\mathrm{C}_{10: 0}-\mathrm{C}_{12: 0}$, respectively), expressed as percentage of total FFA. The addition of EST2 had a significant $(\mathrm{P}<0.05)$ effect on the accumulation of short- and medium- chain fatty acids. Mean values of SCFA (\%) were 2.6 for $\mathrm{C}$ cheeses, and 2.9, 3.4 and 4.3 for $\mathrm{E}_{\mathrm{II}}, \mathrm{E}_{\mathrm{III}}$ and $\mathrm{E}_{\mathrm{IV}}$ cheeses, respectively. For the MCFA (\%), mean values were 4.0 for $\mathrm{C}$ cheeses, and 4.6, 4.7 and 5.2\% for $\mathrm{E}_{\mathrm{II}}, \mathrm{E}_{\mathrm{III}}$ and $\mathrm{E}_{\mathrm{IV}}$ cheeses, respectively. The results highlight an increase of $31 \%$ and $65 \%$ for SCFA and $17 \%$ and $30 \%$ for MCFA, in $\mathrm{E}_{\mathrm{III}}$ and $\mathrm{E}_{\mathrm{IV}}$ cheeses, respectively. In conclusion EST2 acts on triglycerides during cheese ripening producing a preferential release of short and intermediate chain fatty acids.

\subsection{Volatile compounds}

Solid-phase microextraction (SPME) was selected as analytical tool for the isolation of volatile compounds; a series of works have remarked the suitability of this technique for comparing or to discriminate cheese samples with different additives or treatments (Pérès et al., 2001; Chiofalo et al., 2004; Randazzo et al., 2008). A total of 27 and 31 volatile compounds were identified in control and experimental cheeses, respectively. The semi-quantitative results (peak areas in arbitrary units) obtained for control and experimental cheeses were evaluated separately for each trial of cheese making. The main compounds showed a similar pattern as the amount of enzyme increased. Table 3 summarize the volatile compound profiles belonging to one trial of cheese making. Good reproducibility was noted during the analysis. Coefficients of variation (duplicated analyses) of desorption peak areas ranged from 1 to $25 \%$. Similar values were obtained for solid matrices by other authors (Ruiz et al., 1998; Pinho et al., 2003). Statistical differences ( $\mathrm{P} \leq 0.05)$ for area values of the majority of volatile compounds between both types of cheeses were observed.

In this study were taking into account the fat-derived flavour compounds fatty acids, methylketones, esters, linear-chain aldehydes and secondary alcohols (Collins et al., 2003; Alewijn et al., 2003, 2005), because the aim of this work is to study the influence of an esterase on the cheese ripening.

\section{Ketones}

Seven ketones, mainly of the methyl ketones group were identified in cheese samples (Table 3). Methyl ketones have low perception thresholds and they are associated with fruity, floral, musty and blue cheese notes (Molimard \& Spinnler, 1996; Curioni \& Bosset, 2002; Frank et al., 2004). The methyl ketones are important constituents of aroma profile of several varieties of cheeses. In mould-ripened cheeses, some of them such as 2-heptanone and 2-nonanone have been primarily recognized 
Table 3. Volatile compounds identified in control and experimental cheeses by GC-FID-MS. Peak areas obtained were normalized and expressed in arbitrary units of area. Results are mean of two independent results.

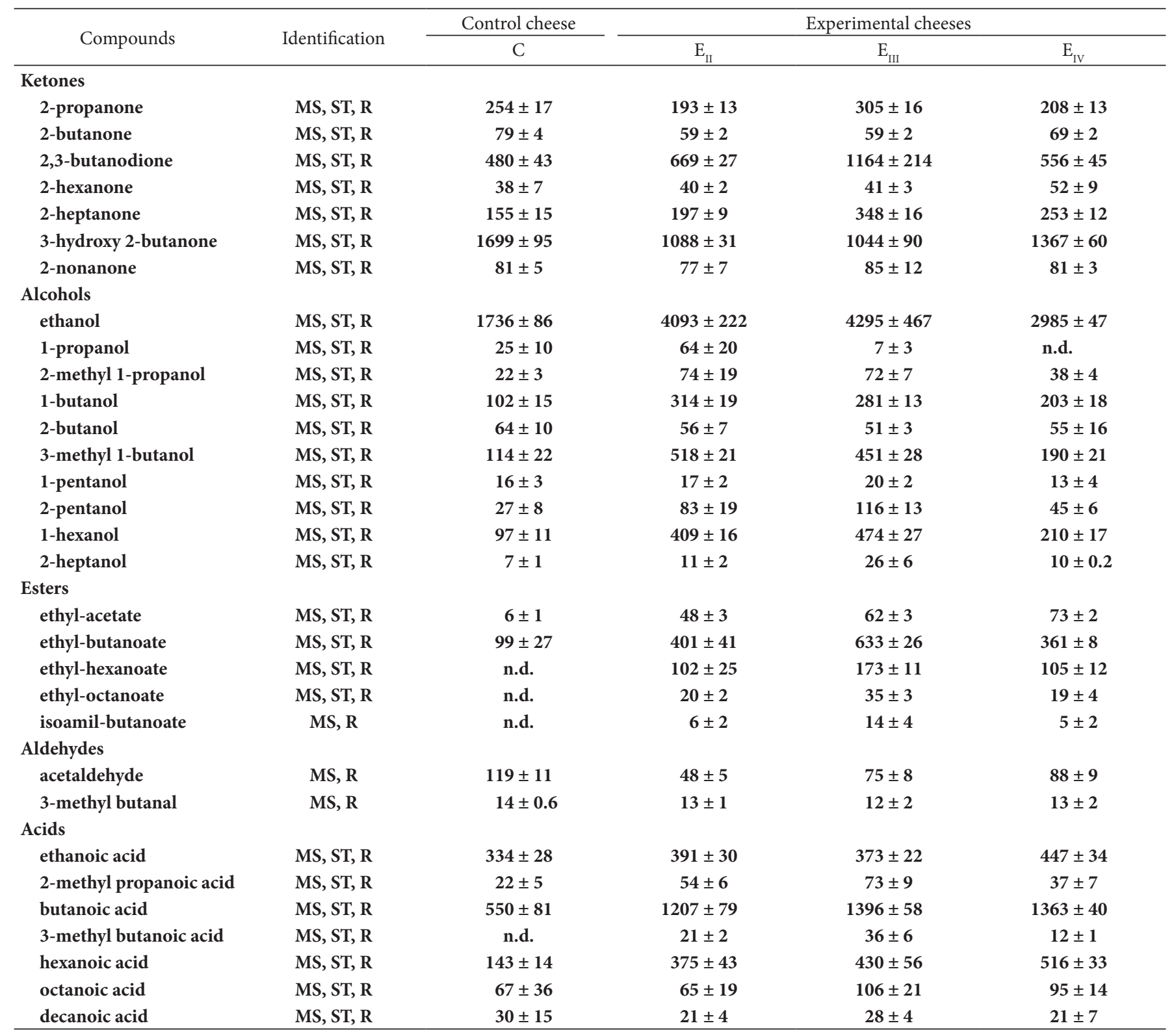

n.d.= not detected; $\mathbf{M S}$ = spectra comparison using NIST-62 Library; ST = authentic standard injection (SigmaAldrich); $\mathbf{R}=$ comparison with published data (Mallia et al., 2005; Ziino et al., 2005; Povolo et al., 2007; Wolf et al., 2011).

as impact compounds, contributing to the characteristic flavour (Sablé \& Cottenceau, 1999; Moio et al., 2000; Curioni \& Bosset, 2002; Qian et al., 2002). The synthesis of methyl ketones in cheeses, especially that of odd number carbon atoms is associated with lipolytic activity of moulds (Molimard \& Spinnler, 1996; Sablé \& Cottenceau, 1999; Collins et al., 2003).

With the exception of 2-hexanone and 2-nonanone, statistical differences between control and experimental cheeses were detected. Particularly, 2-propanone, diacetyl and 2-heptanone showed the higher levels (taking into account the peak area values) in $\mathrm{E}_{\mathrm{III}}$ cheeses, whereas 2-butanone and 3-hydroxy 2-butanone (acetoin) had the higher area values in control cheeses.

\section{Alcohols}

Among this group, a total of ten alcohols having linear chain, branched-chain, secondary and primary alcohols, were identified (Table 3).

It is accepted that aliphatic primary alcohols, such as 1-pentanol and 1-hexanol, contribute with fruity and nutty notes to the flavour (Ziino et al., 2005) and their presence in cheeses is related with lipolytic activity of microorganisms (Barbieri et al., 1994). Ethanol has two different origins: it can derive from lactose or citrate metabolism or from alanine degradation (McSweeney \& Sousa, 2000; Castillo et al., 2007). On the other hand, secondary alcohols, mainly those with odd 
number of carbon atoms, are formed by reduction of methyl ketones (Dartey \& Kinsella, 1971; Collins et al., 2003), and for this reason, their origin is associated to lipolytic process. In the case of branched chain-alcohols 2-methyl propanol and 3-methyl butanol, the amino acid catabolism is considered the metabolic pathway for their formation (Urbach, 1995; Marilley \& Casey, 2004; Smit et al., 2005).

Excluding 2-butanol and 1-pentanol, for others alcohols were detected statistical differences between control and experimental cheeses; in fact, higher levels of ethanol, 1-butanol, 3-metlyl 1-butanol and 1-hexanol were observed in $\mathrm{E}_{\mathrm{II}}$ and $\mathrm{E}_{\mathrm{III}}$ cheeses. Considering the area values, ethanol resulted the most abundant in all cheeses and it has been reported as the majority in some type of cheeses, like Italian Pecorino, Spanish La Serena and Greek Feta (Larráyoz et al., 2001; Carbonell et al., 2002; Bintsis \& Robinson, 2004), although probably it does not contribute to the aroma, due to its high detection threshold. However, the presence of ethanol in sufficient quantities is crucial for the formation of ethyl esters (Holland et al., 2005).

\section{Esters}

Esters are common components of the volatile fraction of cheeses (Table 3). Among the determined esters, most of them were ethyl esters and only one was isoamyl ester. Ethyl esters of fatty acids of $C_{2}$ to $C_{10}$ have been reported as typically present in cheeses, among these ethyl-butanoate and ethyl-hexanoate are considered the most important from a qualitative and quantitative viewpoint (Fenster et al., 2003; Liu et al., 2004; Holland et al., 2005). In control cheeses were detected only two esters (ethyl-acetate and ethyl-butanoate), whereas in experimental cheeses were found also ethyl-hexanoate, ethyl-octanoate and isoamil-butanoate. All esters presented statistical differences among control and experimental cheeses. In particular, ethyl-butanoate and ethyl-hexanoate showed the highest area values. It is well known that they contribute to the overall flavour complexity without a fruity intensity or can be responsible of the fruity character or sweet odour in a wide variety of cheeses (Liu et al., 2004).

\section{Aldehydes}

Two aldehydes were identified in cheese samples (Table 3): acetaldehydes and 3-methyl butanal. Slightly decrease of acetaldehyde was recorded from control to experimental cheeses, whereas for 3-methyl butanal no differences were found among cheeses. The origin of these compounds is related with amino acid catabolism (McSweeney \& Sousa, 2000).

\section{Acids}

A total of seven acids were identified in the samples (Table 3), ethanoic acid, butanoic acid and hexanoic acid had the highest area values. As known, free fatty acids are important, or even predominant, components of cheese flavour (Curioni \& Bosset, 2002), here we detect statistical differences among control and experimental cheeses for ethanoic acid, 2-methyl propanoic acid, butanoic acid, 3-methyl butanoic acid, hexanoic acid and octanoic acid. In particular, butanoic and hexanoic acids reached the greatest levels in $\mathrm{E}_{\mathrm{III}}$ and $\mathrm{E}_{\mathrm{IV}}$ cheeses. These results are in agreement with the higher values of SCFA found in lipolysis analysis.

\section{Conclusions}

The aim of this work was to verify the effect on cheese ripening and in consequence the development of flavours by addition of an exogenous enzyme during cheese making. In particular was chosen the thermophilic esterase EST2 because previously was demonstrated that remain active in milk and cheese models (Mandrich et al., 2006).

The activity of EST2 was not altered in milk. The enzyme distribution between mini-curds and whey in experiences at lab-scale showed an enrichment of EST2 in mini-curds made with whole milk. This fact was not observed using low fat milk, indicating the affinity of EST2 for the fat phase integrated in curd during manufacture.

The addition of EST2 did not alter the steps of milk coagulation and separation of whey during cheese making. Analysis by western blot confirmed that the enzyme distribution between curd and whey was the same as that obtained at lab scale preparation.

Moisture, fat and protein contents, $\mathrm{pH}$ values and degree of ripening were similar among cheeses, showing that EST2 did not modify the ripening profile of cheese samples.

The results of lipolysis profiles indicated clearly an increase of FFA in experimental cheeses in relation to control cheeses. Relative increases of short- $\left(\mathrm{C}_{4: 0}-\mathrm{C}_{8: 0}\right)$ and medium- $\left(\mathrm{C}_{10: 0}-\mathrm{C}_{12: 0}\right)$ chain fatty acids were observed for $\mathrm{E}_{\mathrm{III}}$ and $\mathrm{E}_{\mathrm{IV}}$ cheeses. This fact suggests the preferential catalytic action of EST2 on triglycerides occurring during ripening.

The analysis of volatile compounds revealed a total of twenty-seven and thirty-one compounds in control and experimental cheeses respectively. They belonged to different chemical families such as ketones, alcohols, esters and acids. Experimental cheeses showed the higher areas values than control cheeses for almost all volatile compounds, mainly in those compounds derived from fat. In particular, it was interesting to notice that the $\mathrm{E}_{\text {III }}$ cheese showed the greatest values in spite it had not the highest enzyme level.

The addition of EST2 in cheese-making did not modified the global composition of cheeses, but it had a direct effect on lipolysis and free fatty acid catabolism due to the increase of compounds derived from milk fats (free fatty acids, alcohols, methyl ketones and esters). The ability of EST2 to hydrolyze esters, thioesters and to synthesize short esters in cheese matrix was previously assessed (Mandrich et al., 2006); the analysis made on the experimental cheeses (Table 3 ) confirms these abilities.

Previously, other results have been collected regarding the use of exogenous lipases during cheese making, and in all cases an increase of lipolysis and volatile compounds were detected (Hernández et al., 2005; Spelbrink et al., 2015). Here we observed two important differences in addition to the well known structural and substrate differences between lipases and esterases, which are the time of ripening and the amount of added enzymes; in 
fact, we tested the experimental cheeses at 8 weeks of ripening, respect 13 weeks used for patatin lipase (Spelbrink et al., 2015) and from 13 to 26 weeks for commercial lipases (Hernández et al, 2005), and being EST2 highly stable we used a lower quantity of enzymes respect the lipases above reported (Hernández et al., 2005; Mandrich et al., 2006; Spelbrink et al., 2015). Therefore, the use of EST2 as an ingredient in cheese making could be considered as an interesting tool to increase the cheese flavour and to reduce the time of ripening.

Obviously, these data are preliminary and an eventual use in dairy industry must be preceded by rigorous toxicological tests and a market investigation in order to understand if the consumers would be well disposed to the eating of cheeses elaborated in this way.

\section{Acknowledgements}

This work was supported by the Italian National Research Council (CNR) and Consejo Nacional de Investigaciones Cientificas y Tecnicas (CONICET, Argentina).

\section{References}

Alewijn, M., Sliwinski, E. L., \& Wouters, J. T. (2003). A fast and simple method for quantitative determination of fat-derived medium and low-volatile compounds in cheese. International Dairy Journal, 13(9), 733-741. http://dx.doi.org/10.1016/S0958-6946(03)00098-0.

Alewijn, M., Sliwinski, E. L., \& Wouters, J. T. (2005). Production of fat-derived (flavour) compounds during the ripening of Gouda cheese. International Dairy Journal, 15(6-9), 733-740. http://dx.doi. org/10.1016/j.idairyj.2004.09.009.

Arpigny, J. L., \& Jaeger, K.-L. (1999). Bacterial lipolitic enzymes: classification and propeerties. The Biochemical Journal, 343(1), 177-183. http://dx.doi.org/10.1042/bj3430177. PMid:10493927.

Barbieri, G., Bolzoni, L., Careri, M., Mangia, A., Parolari, G., Spagnoli, S., \& Virgili, R. (1994). Study of the volatile fraction in Parmesan cheese. Journal of Agricultural and Food Chemistry, 42(5), 1170-1176. http://dx.doi.org/10.1021/jf00041a023.

Battistotti, B., \& Corradini, C. (1993). Italian cheese. In P. F. Fox (Eds.), Cheese: chemistry, physics and microbiology (Vol. 2, pp. 221-243). London: Chapman \& Hall.

Bergamini, C. V., Hynes, E. R., \& Zalazar, C. A. (2006). Influence of probiotic bacteria on the proteolysis profile of a semi-hard cheese. International Dairy Journal, 16(8), 856-866. http://dx.doi.org/10.1016/j. idairyj.2005.09.004.

Bintsis, T., \& Robinson, R. K. (2004). A study of the effect of adjunct cultures on the aroma compounds of Feta-type cheese. Food Chemistry, 88(3), 435-441. http://dx.doi.org/10.1016/j.foodchem.2004.01.057.

Bradley, R. L., Arnold, E., Barbano, D. M., Semerad, R. G., Smith, D. E., \& Vines, B. K. (1993). Chemical and physical methods. In R. Marshall (Ed.), Standard methods for the examination of dairy products (pp. 433-531). Washington: American Public Health Association.

Carbonell, M., Nunez, M., \& Fernandez-Garcia, E. (2002). Seasonal variation of volatile compounds in ewe raw milk La Serena cheese. Le Lait, 82(6), 699-711. http://dx.doi.org/10.1051/lait:2002043.

Castillo, I., Calvo, M., Alonso, L., Juárez, M., \& Fontecha, J. (2007). Changes in lipolysis and volatile fraction of a goat cheese manufactured employing a hygienized rennet paste and a defined strain starter.
Food Chemistry, 100(2), 590-598. http://dx.doi.org/10.1016/j. foodchem.2005.09.081.

Chiofalo, B., Zumbo, A., Costa, R., Liotta, L., Mondello, L., Dugo, P., \& Chiofalo, V. (2004). Characterization of Maltese goat milk cheese flavour using SPME_GC/MS. South African Journal of Animal Science, 34, 176-180.

Collins, Y. F., McSweeney, P. L. H., \& Wilkinson, M. G. (2003). Lipolysis and free fatty acid catabolism in cheese: a review of current knowledge. International Dairy Journal, 13(11), 841-866. http:// dx.doi.org/10.1016/S0958-6946(03)00109-2.

Curioni, P. M. G., \& Bosset, J. O. (2002). Key odorants in various cheese types as determined by gas chromatography-olfactometry. International Dairy Journal, 12(12), 959-984. http://dx.doi.org/10.1016/ S0958-6946(02)00124-3.

Dartey, C. K., \& Kinsella, J. E. (1971). Rate of formation of methyl ketones during blu cheese ripening. Journal of Agricultural and Food Chemistry, 19(4), 771-774. http://dx.doi.org/10.1021/jf60176a029.

De Simone, G., Galdiero, S., Manco, G., Lang, D., Rossi, M., \& Pedone, C. (2000). A snapshot of a transition state analogue of a novel thermophilic esterase belonging to the subfamily of mammalian hormone-sensitive lipase. Journal of Molecular Biology, 303(5), 761-771. http://dx.doi.org/10.1006/jmbi.2000.4195. PMid:11061974.

El Soda, M. (2003). Accelerated cheese ripening. In H. Roginsky, J. W. Fuquay \& P. F. Fox (Eds.): Encyclopedia of dairy science (pp. 327328). Cornwall: Academic Press.

El-Hofi, M., El-Tanboly, E.-S., \& Abd-Rabou, N. (2011). Industrial application of lipases in cheese making: a review. Internet Journal of Food Safety, 13, 293-302.

Fenster, K., Rankin, S., \& Steele, J. (2003). Accumulation of short- $n$ chain ethyl esters by esterase of lactic bacteria under conditions simulating ripening Parmesan cheese. Journal of Dairy Science, 86(9), 2818-2825. http://dx.doi.org/10.3168/jds.S0022-0302(03)73879-X. PMid:14507018.

International Dairy Federation - FIL-IDF. (1982). Cheese and fused cheese: determination of dry matter: reference method $n^{\circ} 4: A$. Brussels: FIL-IDF.

International Dairy Federation - FIL-IDF. (1993). Milk: determination of nitrogen content: reference method $n^{\circ}$ 20:B. Brussels: FIL-IDF.

International Dairy Federation - FIL-IDF. (1995). Milk and dairy product: guide de l'echantillonnange: standard reference method $n^{\circ}$ 50C. Brussels: FIL-IDF.

Fox, P. F. (1993). Cheese: chemistry, physics and microbiology (Vol. 1, pp. 1-36). London: Chapman \& Hall.

Frank, D. C., Owen, C. M., \& Patterson, J. (2004). Solid phase microextraction (SPME) combined with gas-chromatography and olfactometry-mass spectrometry for characterization of cheese aroma compounds. Lebensmittel-Wissenschaft + Technologie, 37(2), 139-154. http://dx.doi.org/10.1016/S0023-6438(03)00144-0.

Gripon, J. C., Desmazeaud, M. J., Le Bars, D., \& Bergère, J. L. (1975). Etude du rôle des micro-organismes et des enzymes an cours de la maturation des fromages. II. Influence de la prèsure commerciale. Le Lait, 55(548), 502-516. http://dx.doi.org/10.1051/lait:197554828.

Harboe, M. K. (1994). Use of lipases in cheese-making. Bulletin of the International Dairy Federation, 294, 11-16.

Hernández, I., de Renobales, M., Virto, M., Pérez-Elortondo, F., Barron, L., Flanagan, C., \& Albisu, M. (2005). Assessment of industrial lipases for flavour development in commercial Idiazabal (ewe's raw milk) cheese. Enzyme and Microbial Technology, 36(7), 870-879. http:// dx.doi.org/10.1016/j.enzmictec.2004.12.032. 
Holland, R., Liu, S.-Q., Crow, V. L., Delabre, M.-L., Lubbers, M., Bennett, M., \& Norris, G. (2005). Esterases of lactic acid bacteria and cheese flavour: milk fat hydrolysis, alcoholysis and esterification. International Dairy Journal, 15(6-9), 711-718. http://dx.doi. org/10.1016/j.idairyj.2004.09.012.

International Organization for Standardization - ISO. (1975). ISO 3433: cheese: determination of fat content: Van Gulik method. Switzerland: ISO.

Khan, F. I., Lan, D., Durrani, R., Huan, W., Zhao, Z., \& Wang, Y. (2017). The lid domain in lipases: structural and functional determinant of enzymatic properties. Frontiers in Bioengineering and Biotechnology, 5, 16. http://dx.doi.org/10.3389/fbioe.2017.00016. PMid:28337436.

Kilara, A. (2003). Lipases. In H. Roginsky, J. W. Fuquay \& P. F. Fox (Eds.), Encyclopedia of dairy science (pp. 914-918). Cornowall: Academic Press.

Larráyoz, P., Addis, M., Gauch, R., \& Bosset, J. B. (2001). Comparison of dynamic headspase and simultaneous distillation extraction techniques used for the analysis of the volatile components in the three European PDO ewes milk cheeses. International Dairy Journal, 11(11-12), 911-926. http://dx.doi.org/10.1016/S0958-6946(01)00144-3.

Liu, S.-Q., Holland, R., \& Crow, V. L. (2004). Esters and their biosynthesis in fermented dairy products. International Dairy Journal, 14(11), 923-945. http://dx.doi.org/10.1016/j.idairyj.2004.02.010.

Mallia, S., Fernández-García, E., \& Olivier Bosset, J. (2005). Comparison of purge and trap and solid phase microextraction techniques for studing the volatile aroma compounds of three European PDO hard cheeses. International Dairy Journal, 15(6-9), 741-758. http:// dx.doi.org/10.1016/j.idairyj.2004.11.007.

Manco, G., Adinolfi, E., Pisani, F. M., Ottolina, G., Carrea, G., \& Rossi, M. (1998). Overexpression and properties of a new thermostable esterase from Bacillus acidocaldarius with sequence similarity to hormone sensitive lipase subfamily. The Biochemical Journal, 332(1), 203-212. http://dx.doi.org/10.1042/bj3320203. PMid:9576869.

Manco, G., Mandrich, L., \& Rossi, M. (2001). Residue at the active site of the esterase 2 from Alyciclobacillus acidocaldarius involved in substrate specificity and catalytic activity at high temperature. The Journal of Biological Chemistry, 276(40), 37482-37490. http:// dx.doi.org/10.1074/jbc.M103017200. PMid:11447219.

Mandrich, L., Manco, G., Rossi, M., Floris, E., Jansen-van den Bosch, T., Smit, G., \& Wouters, J. A. (2006). Thermophilic esterase EST2 from Alyciclobacillus acidocaldarius acts in milk and cheese model. Applied and Environmental Microbiology, 72(5), 3191-3197. http:// dx.doi.org/10.1128/AEM.72.5.3191-3197.2006. PMid:16672457.

Marilley, L., \& Casey, M. G. (2004). Flavours of cheese products: metabolic pathways, analytical tools and identification of producing strains. International Journal of Food Microbiology, 90(2), 139-159. http://dx.doi.org/10.1016/S0168-1605(03)00304-0. PMid:14698096.

McSweeney, P. L. H., \& Sousa, M. J. (2000). Biochemical pathways for the production of flavours compounds in cheese during ripening: a review. Le Lait, 80(3), 293-324. http://dx.doi.org/10.1051/lait:2000127.

Meinardi, C. A., Alonso, A., Hynes, E., \& Zalazar, C. A. (2002). Influence of milk-clotting enzymes on acidification rate of natural whey starter culture. International Journal of Dairy Technology, 55(3), 139-144. http://dx.doi.org/10.1046/j.1471-0307.2002.00052.x.

Moio, L., Piombino, P., \& Addeo, F. (2000). Odour-impact compounds of Gorgonzola cheese. The Journal of Dairy Research, 67(2), 273-285. http://dx.doi.org/10.1017/S0022029900004106. PMid:10840681.

Molimard, P., \& Spinnler, H. E. (1996). Compounds involved in the flavour of surface Mold-ripened cheeses: origins and properties.
Journal of Dairy Science, 79(2), 169-184. http://dx.doi.org/10.3168/ jds.S0022-0302(96)76348-8.

Pérès, C., Viallon, C., \& Berdagué, J. L. (2001). Solid-phase microextractionmass spectrometry: a new approach to the rapid characterization of cheeses. Analytical Chemistry, 73(5), 1030-1036. http://dx.doi. org/10.1021/ac001146j. PMid:11289413.

Perotti, M. C., Bernal, S. M., Meinardi, C. A., \& Zalazar, C. A. (2005). Free fatty acids profiles of Reggianito Argentino cheese produced with different starter. International Dairy Journal, 15(11), 1150-1155. http://dx.doi.org/10.1016/j.idairyj.2004.11.005.

Pinho, O., Pérès, C., \& Ferreira, I. M. (2003). Solid-phase microextraction of volatile compounds in "Terrincho" ewe cheese: comparison of different fibbers. Journal of Chromatography. A, 1011(1-2), 1-9. http://dx.doi.org/10.1016/S0021-9673(03)01066-5. PMid:14518757.

Povolo, M., Contarini, G., Mele, M., \& Secchiari, P. (2007). Study on the influence of pasture on volatile fraction of ewe' dairy products by solid-phase microextraction and gas chromatography-mass spectrometry. Journal of Dairy Science, 90(2), 556-569. http://dx.doi. org/10.3168/jds.S0022-0302(07)71539-4. PMid:17235132.

Qian, M., Nelson, C., \& Bloomer, S. (2002). Evaluation of fat-derived aroma compounds in blue cheese by dynamic headspace GC/ Olfactometry-MS. Journal of the American Oil Chemists' Society, 79(7), 663-667. http://dx.doi.org/10.1007/s11746-002-0540-4.

Randazzo, C. L., Pitino, I., De Luca, S., Scifò, G. O., \& Caggia, C. (2008). Effect of wild strains used as starter cultures and used as starter cultures and adjunct cultures on the volatile compounds of the Pecorino Siciliano cheese. International Journal of Food Microbiology, 122(3), 269-278. http://dx.doi.org/10.1016/j.ijfoodmicro.2007.12.005. PMid:18281116.

Reinheimer, J. A., Quiberoni, A., Tailliez, P., Binetti, A. G., \& Suàrez, V. (1996). The lactic acid microflora of natural whey starters used in Argentina for hard cheese production. International Dairy Journal, 6(8-9), 869-879. http://dx.doi.org/10.1016/0958-6946(96)00014-3.

Ruiz, J., Cava, R., Ventanas, J., \& Jensen, M. (1998). Headspace solid phase microextraction for the analysis of volatiles in a meat product: dry-cured Iberian ham. Journal of Agricultural and Food Chemistry, 46(11), 4688-4694. http://dx.doi.org/10.1021/jf980139h.

Sablé, S., \& Cottenceau, G. J. (1999). Current knowledge of soft cheeses flavour and related compounds. Journal of Agricultural and Food Chemistry, 47(12), 4825-4836. http://dx.doi.org/10.1021/jf990414f. PMid:10606538.

Smit, G., Smit, B. A., \& Engels, W. J. M. (2005). Flavour formation by lactic acid bacteria and biochemical flavours profiling of cheese products. FEMS Microbiology Reviews, 29(3), 591-610. http://dx.doi. org/10.1016/j.fmrre.2005.04.002. PMid:15935512.

Spelbrink, R. E. J., Lensing, H., Egmond, M. R., \& Giuseppin, M. L. F. (2015). Potato patatin generates short-chain fatty acids from milk fat than contribute to flavour development in cheese ripening. Applied Biochemistry and Biotechnology, 176(1), 231-243. http:// dx.doi.org/10.1007/s12010-015-1569-3. PMid:25809992.

Upadhyay, V., Sousa, M., Ravn, P., Israelsen, H., Kelly, A., \& McSweeney, P. L. H. (2004). Use of exogenous streptokinase to accelerate proteolysis in Cheddar cheese. Le Lait, 84(6), 527-538. http://dx.doi. org/10.1051/lait:2004022.

Urbach, G. (1995). Contribution of lactic acid bacteria to flavour compound formation in dairy products. International Dairy Journal, 5(8), 877-903. http://dx.doi.org/10.1016/0958-6946(95)00037-2.

Wolf, I. V., Perotti, M. C., \& Zalazar, C. A. (2011). Composition and volatile profiles of commercial Argentinean blue cheeses. Journal 
De Luca et al.

of the Science of Food and Agriculture, 91(2), 385-393. http://dx.doi. org/10.1002/jsfa.4198. PMid:20981732.

Yvon, M., \& Rijnen, L. (2001). Cheese flavour formation by amino acid catabolism. International Dairy Journal, 11(4-7), 185-201. http:// dx.doi.org/10.1016/S0958-6946(01)00049-8.
Ziino, M., Condurso, C., Romeo, V., Giuffrida, D., \& Verzera, A. (2005). Characterization of "Provola dei Nebridi" a typical Sicilian cheese, by volatile analysis using SPME-GC/MS. International Dairy Journal, 15(6-9), 585-593. http://dx.doi.org/10.1016/j. idairyj.2004.07.024. 
Appendix A. Technical details for the free fatty acids ( $i$ ) and volatiles compounds profiles (ii) by GC-FID analysis.

\section{i) Free fatty acids analysis by GC-FID}

A Perkin Elmer model GC-9000 series gas chromatograph (Perkin Elmer Corp. Waltham, Massachusetts, USA) equipped with a flame ionization detector (FID), and with a split/splitless injector was used. FFA were separated on a fused-silica capillary column (PE-Wax, $60 \mathrm{~m} \times 0.25 \mathrm{~mm})$ coated with a bonded polyethylene glycol stationary phase $(0.25 \mu \mathrm{m}$ layer thickness). Chromatographic conditions were as follows: initial $75^{\circ} \mathrm{C}(1.5 \mathrm{~min})$, up to $150^{\circ} \mathrm{C}(3 \mathrm{~min})$ at $8{ }^{\circ} \mathrm{C} / \mathrm{min}$, up to a final temperature of $230^{\circ} \mathrm{C}(15 \mathrm{~min})$ at $10{ }^{\circ} \mathrm{C} / \mathrm{min}$, nitrogen flow $2 \mathrm{~mL} / \mathrm{min}$ and the split ratio $1: 50$. The injector and detector temperatures were $250{ }^{\circ} \mathrm{C}$ and $300{ }^{\circ} \mathrm{C}$, respectively. Enantic $\left(\mathrm{C}_{7: 0}\right)$ and margaric acids $\left(\mathrm{C}_{17: 0}\right)$ (Sigma Aldrich, USA) were used as internal standards for the quantification of $\mathrm{C}_{4: 0}$ to $\mathrm{C}_{18: 2}$. Calibration curves were prepared by combining increasing concentrations of a mixture of butyric $\left(\mathrm{C}_{4: 0}\right)$, caproic $\left(\mathrm{C}_{6: 0}\right)$, caprylic $\left(\mathrm{C}_{8: 0}\right)$, capric $\left(\mathrm{C}_{10: 0}\right)$, lauric $\left(\mathrm{C}_{12: 0}\right)$, myristic $\left(\mathrm{C}_{14: 0}\right)$, palmitic $\left(\mathrm{C}_{16: 0}\right)$, stearic $\left(\mathrm{C}_{18: 0}\right)$, oleic $\left(\mathrm{C}_{18: 1}\right)$ and linoleic $\left(\mathrm{C}_{18: 2}\right)$ fatty acids, with fixed concentrations of enantic $\left(\mathrm{C}_{7: 0}\right)$ and margaric $\left(\mathrm{C}_{17: 0}\right)$ acids. The FID out signal was recorded and the chromatograms were processed using Turbochrom v. 4 software (Perkin Elmer Corp. Waltham, Massachusetts, USA).

\section{ii) Volatiles compounds profiles by GC-FID-MS}

The vials were thermostatized at $40 \pm 1{ }^{\circ} \mathrm{C}$ for 10 minutes and then the fiber was exposed to the headspace for 15 minutes. After exposure, the fiber was thermally desorbed into a $\mathrm{GC}$ and left in the injection port (equipped with a $0.75 \mathrm{~mm}$ i.d. inlet liner) for 5 minutes. The injector was set at $250{ }^{\circ} \mathrm{C}$ and operated in the splitless mode. A GC coupled to a flame ionization detector (Perkin Elmer Model 9000) was used to obtain information of peak areas (expressed in arbitrary units of area). The volatile components were separated on the same column employed in the free fatty acid analyses. The oven temperature program was: $45^{\circ} \mathrm{C}(4 \mathrm{~min}), 8^{\circ} \mathrm{C} / \mathrm{min}$ to $150^{\circ} \mathrm{C}(3 \mathrm{~min}), 10^{\circ} \mathrm{C} / \mathrm{min}$ to $250^{\circ} \mathrm{C}(5 \mathrm{~min})$. The carrier gas was nitrogen at flow rate of $2 \mathrm{~mL} / \mathrm{min}$. A GC coupled to an ion trap mass spectrometer (GC-MS Shimadzu QP-5000) was used to identify the compounds under the same chromatographic conditions using the same column of CG-FID analysis. Mass spectra were obtained with $70 \mathrm{eV}$ electron impact ionization (EI mode). The mass range used was 42 to $300 \mathrm{~m} / \mathrm{z}$ (scan rate $250 \mathrm{amu} / \mathrm{seg}$ ). The identification of volatile compounds was obtained by matching mass spectra with the Nist-62 library of standard compounds. 